\title{
The extent and patterns of usage of Agent Orange and other herbicides in Vietnam
}

\author{
Jeanne Mager Stellman*, Steven D. Stellman†‡, Richard Christian $\S$, Tracy Weber* \& Carrie Tomasallo* \\ * Departments of Health Policy and Management and †Epidemiology, Mailman School of Public Health, Columbia University, 600 West 168th Street, New York, \\ New York 10032, USA \\ ¥Institute for Cancer Prevention, One Dana Road, Valhalla, New York 10595, USA \\ $\$ 2102$ Old Stage Road, Alexandria, Virginia 22308, USA
}

Herbicides including Agent Orange were sprayed by United States forces for military purposes during the Vietnam War (19611971) at a rate more than an order of magnitude greater than for similar domestic weed control. In 1974, the US National Academy of Sciences published estimates of the extent and distribution of herbicides sprayed. Here we present revised estimates, developed using more-complete data. The spray inventory is expanded by more than seven million litres, in particular with heavily dioxin-contaminated herbicides. Estimates for the amount of dioxin sprayed are almost doubled. Hamlet census data reveal that millions of Vietnamese were likely to have been sprayed upon directly. Our identification of specific military herbicide targets has led to a more coherent understanding of spraying. Common errors in earlier interpretations of the spray data are also discussed.

Between 1961 and 1971 herbicide mixtures, nicknamed by the coloured identification band painted on their 208-litre storage barrels, were used by United States and Republic of Vietnam forces to defoliate forests and mangroves, to clear perimeters of military installations and to destroy 'unfriendly' crops as a tactic for decreasing enemy food supplies ${ }^{1}$. The best-known mixture was Agent Orange. About $65 \%$ of the herbicides contained 2,4,5trichlorophenoxyacetic acid $(2,4,5-\mathrm{T})$, which was contaminated with varying levels of 2,3,7,8-tetrachlorodibenzo-p-dioxin (TCDD). Herbicide mixtures are listed in Table 1.

In 1970, the US Congress directed the US Department of Defense (DoD) to engage the National Academy of Sciences to conduct a comprehensive study (NAS-1974) of the ecological and physiological effects of defoliation in Vietnam ${ }^{2}$. NAS-1974 relied on a chronological record, the HERBS file ${ }^{3}$, which contained flight path coordinates of Air Force spraying missions carried out between August 1965 and December 1971 and from 1968 on US Army helicopter spraying missions. In 1985, the DoD supplemented this file with the Services-HERBS file, derived from additional record searches. The HERBS file error rate was about $10 \%$, attributable largely to transcription, data entry and pilot recording errors ${ }^{4}$. Under contract to the NAS, using data more complete than were then available, we undertook, in close collaboration with the US Armed Services Center for Research of Unit Records (CRUR), to correct both files (see Methods) and during this process discovered much additional archived data.

Military herbicide operations in Vietnam became a matter of scientific controversy from their inception ${ }^{5,6}$. In April 1970, 2,4,5-T was banned from most US domestic uses, on the basis of evidence of its teratogenicity ${ }^{7}$. The Agent Orange Act of 1991 requested the Institute of Medicine (IOM) to assess the strength of the evidence for association between exposure to military herbicides and disease in veterans and the feasibility of conducting further epidemiological studies. The IOM recommended that the Department of Veterans Affairs develop historical reconstruction methods for characterizing exposure to herbicides in Vietnam ${ }^{8,9}$. The present report is the result of that recommendation.

\section{Background to military use of chemical defoliants}

The DoD's Advanced Research Project Agency's (ARPA) Project Agile was instrumental in the US development of herbicides as a military weapon, an undertaking inspired by the successful British use of 2,4,5-T to destroy jungle-grown crops during the insurgency in Malaya. ARPA supported tests on combinations and concentrations of herbicides; calibration studies of the spray delivery system to achieve the desired $281 \mathrm{ha}^{-1}$ (3 gallons/acre) rate; and experiments on optimal conditions to minimize spray $\mathrm{drift}^{10}$. ARPA also developed the Hamlet Evaluation System ${ }^{11}$ which collected the political census data that we use here for estimating population exposures.

The first large-scale US military defoliation took place in Camp Drum, New York, in 1959, using Agent Purple (a 50:50 mixture of 2,4-D and 2,4,5-T) and a spray system which was the model for those used in Vietnam. Herbicide tests were run from August to December 1961 in the Republic of Vietnam (RVN), using dinoxol and trinoxol $^{12,13}$. An insecticide test series was also undertaken. The first major herbicide shipment arrived in RVN in January 1962; defoliation targets were sprayed during September and October 1962 (Agent Purple); crop destruction targets were sprayed in November 1962 (Agent Blue $)^{14}$. Systematic testing of herbicides and calibration of herbicide delivery systems continued for several years ${ }^{15}$.

A 1962 pact assigned ownership of the herbicides to RVN when they entered its territory. Vietnamese physically handled the herbicides during off-loading, transport, and transfer to storage tanks. RVN ownership complicated United States Air Force (USAF) logistics and record-keeping, and disposal when Agent Orange use was abandoned in mid-1970 (ref. 16). US policy emphasized that its forces were assisting the RVN in the herbicide programme. C-123 aircraft carried out the missions camouflaged and equipped with removable identification insignias. Crop destruction aircraft bore South Vietnamese markings and were accompanied by a Vietnamese crew member under a State Department/DoD concept known as Farmgate ${ }^{17}$. Flight crew wore civilian clothing.

\section{The herbicide targets and US Air Force project folders}

US Air Force (USAF) operations, codenamed Operation Ranch Hand, dispersed more than $95 \%$ of all herbicides used in Operation 
Trail Dust, the overall herbicide programme. Other branches of the US armed services and RVN forces, generally using hand sprayers, spray trucks (Buffalo turbines), helicopters and boats, sprayed much smaller quantities of herbicide. Operation Ranch Hand was organized into projects that underwent a complex combined South Vietnamese and US approval system which could sometimes last as long as one year. Each project consisted of specific targets that were often amended or deleted during the approval process. Crop destruction also required White House approval until 1963, after which final approval was delegated to the US Ambassador to the RVN.

We reconstructed the project number to which each mission in the HERBS file belonged by concatenating two data fields. Aggregating missions by project number transforms the HERBS file from a chronological listing of criss-crossing flight paths into targetrelated groups of flights flown at different points in time (Figs 1 and 2 ). The importance of projects and targets has not been sufficiently appreciated. NAS-1974, and even the USAF itself ${ }^{18}$, inverted the hierarchy thus: "All missions within a target formed a project".

With US National Archives staff assistance we located a collection of USAF operational project folders for about $50 \%$ of the projects and nearly $60 \%$ of the volume of herbicide inventoried in the HERBS file ${ }^{19}$. Many folders contained 'after action reports' or other documentation on completed missions which had not been included in any HERBS file and permitted us to identify some 200 new missions that pre-date August 1965, the date of the earliest missions on the NAS-1974 HERBS file. The early years of the Vietnam War have incorrectly been regarded as of minor importance with regard to herbicide spraying. In total, about 1.9 million litres of Agent Purple were sprayed between 1962 and 1965, which is particularly significant because herbicides manufactured in the early 1960s were almost certainly more heavily TCDD-contaminated than those produced later ${ }^{20}$. Further, pre-1965 spraying was limited to a relatively small area (Fig. 1c), which thus may be at particular risk for TCDD contamination. Recent data on TCDD residues in soil sampled near US Army Special Forces camps where Agent Purple was sprayed ${ }^{21}$, and results of soil assays at the testing grid in Eglin Air Force Base, Florida ${ }^{22}$, support this interpretation.

\section{Revised spray inventory}

We have re-estimated the volume and type of herbicides sprayed between 1961 and 1971 to have 7,131,907 more litres than the 'uncorrected' NAS-1974 inventory and 9,440,028 1 more than NAS1974 's 'corrected' inventory, in which about $10 \%$ of all missions had been discarded because of obvious recording errors. Figure 3 shows the areas sprayed; Fig. 4 shows the yearly distribution of spray; Fig. 5 shows the numbers of sorties flown, 1961-1971. Table 2 gives estimates of the frequency with which land areas were repeatedly sprayed.

Contamination of $2,4,5$ - $\mathrm{T}$ with TCDD varied widely by production run, manufacturer, and the percentage 2,4,5- $\mathrm{T}$ in the formulation. In early 1966, Agent White, which did not contain 2,4,5-T and hence was not TCDD-contaminated, began to replace Agent Orange. Chemical market forces had led to a shortage of Agent Orange. From a tactical perspective, Agent White was less satisfactory than Agent Orange because several weeks were required for defoliation to begin. It was accepted by the DoD, however, because Agent Orange would apparently no longer be available in sufficient quantities ${ }^{23}$. Agent Blue was the agent of choice for crop destruction by desiccation throughout the entire War, but more than four million litres of the other agents, primarily containing 2,4,5-T, were also used on crops.

Procurement records show that at least 464,164l of Agent Pink and 31,0261 of Agent Green, with comparatively higher TCDD levels, were purchased, but we have been able to document little more than 50,0001 as having been sprayed in RVN and about 15,0001 that were used in tests. We have identified missions which dispersed about 1.9 million litres of Agent Purple, but available procurement data show purchase of only 548,100l (ref. 24), indicating that the procurement records are incomplete.

\section{Extent of dioxin contamination}

Estimates of how much TCDD was deposited in Vietnam are based on the volume of 2,4,5-T-containing herbicide sprayed (which has been revised upward on the basis of the new inventory), and on TCDD contamination levels. Estimates of the mean contamination level used by the USAF ${ }^{18}$ and by NAS-1974 are probably too low.

\begin{tabular}{|c|c|c|c|c|}
\hline Name & $\begin{array}{l}\text { Chemical } \\
\text { constituents }\end{array}$ & $\begin{array}{c}\text { Concentration active } \\
\text { ingredient }\end{array}$ & Years used & $\begin{array}{l}\text { Estimated quantities } \\
\text { sprayed (litres) })^{*}\end{array}$ \\
\hline Agent Pink† & $\begin{array}{l}60 \%-40 \% \text { n-Butyl: isobutyl ester } \\
\text { of } 2,4,5-T \S\end{array}$ & $\begin{array}{l}961-1,081 \mathrm{gl}^{-1} \\
\text { acid equivalent } \neq\end{array}$ & $1961 ; 1965$ & $\begin{array}{l}50,312 \text { sprayed; } 413.852 \text { additional } \\
\text { on procurement records }\end{array}$ \\
\hline Agent Green† & n-Butyl ester 2,4,5-T & $\begin{array}{l}\text { (Should have same acid } \\
\text { equivalent as Agent Pink) }\end{array}$ & $\begin{array}{l}\text { (Unclear but within } \\
\text { timeframe for Agent Pink) }\end{array}$ & $\begin{array}{l}31,026 \text { shown on procurement } \\
\text { records }\end{array}$ \\
\hline Agent Purple† & $\begin{array}{l}50 \% \text { n-Butyl ester 2,4,-D; } \\
30 \% \text { n-butyl ester 2,4,5-T; } \\
20 \% \text { isobutyl ester 2,4,5-T }\end{array}$ & $1,033 \mathrm{gl}^{-1}$ acid equivalent & $1962-1965$ & $1,892,773$ \\
\hline Agent Orange† & $\begin{array}{l}50 \% \text { n-Butyl ester 2,4,-D; } \\
50 \% \text { n-butyl ester 2,4,5-T }\end{array}$ & $1,033 \mathrm{gl}^{-1}$ acid equivalent & $1965-1970$ & $\begin{array}{l}\text { 45,677,937 (may include Agent } \\
\text { Orange II) }\end{array}$ \\
\hline Agent Orange $\| \dagger$ & $\begin{array}{l}50 \% \text { n-Butyl ester 2,4-D; } \\
50 \% \text { isooctyl ester 2,4,5T }\end{array}$ & $910 \mathrm{gl}^{-1}$ acid equivalent & After 1968 (?) & $\begin{array}{l}\text { Unknown but at least 3,591,000 } \\
\text { shipped }\end{array}$ \\
\hline Agent Whitell & $\begin{array}{l}\text { Acid weight basis: } 21.2 \% \\
\text { tri-isopropanolamine salts of } 2,4-D \\
\text { and } 5.7 \% \text { picloram }\end{array}$ & $\begin{array}{l}\text { By acid weight: } 240.2 \mathrm{gl}^{-1} \\
2,4,-D \text { and } 64.9 \mathrm{gl}^{-1} \text { picloram }\end{array}$ & $1966-1971$ & $20,556,525$ \\
\hline $\begin{array}{l}\text { Agent Blue } \\
\text { (powder)ף }\end{array}$ & $\begin{array}{l}\text { Cacodylic acid (dimethylarsinic } \\
\text { acid) and sodium cacodylate }\end{array}$ & $\begin{array}{l}\text { Acid: } 65 \% \text { active ingredient; } \\
\text { salt: } 70 \% \text { active ingredient }\end{array}$ & $1962-1964$ & 25,650 \\
\hline $\begin{array}{l}\text { Agent Blue } \\
\left(\mathrm{H}_{2} \mathrm{O} \text { solution }\right)\end{array}$ & $\begin{array}{l}21 \% \text { sodium cacodylate }+ \\
\text { cacodylic acid to yield at least } 26 \% \\
\text { total acid equivalent by weight }\end{array}$ & Acid weight: $360.3 \mathrm{gl}^{-1}$ & $1964-1971$ & $4,715,731$ \\
\hline
\end{tabular}

Other chemicals used in testing programme but not in Vietnam operations include Modified Orange (4-amino-3,5,6-trichloropicolinic acid (picloram) added to Orange), Dalapon, Bromacil, Tandex, Monuron, Diuron and maleic hydrazide. Dinoxol (1890 I) (butoxyethanol esters of 2,4-dichlorophenoxyacetic acid (2,4-D) and 2,4,5-T), Trinoxol (1455 I) (40\% ethanol ester of 2,4,5-T) and 378 I Conc D (30\% ethyl ester of 2,4,-D in $\mathrm{H}_{2} \mathrm{O}$ ) were also used in tests during 1961.

ethyl ester of $2,4,-\mathrm{D}$ in $\mathrm{H}_{2} \mathrm{O}$ ) were also
${ }^{*}$ Nominal application rate: $4.78 \mathrm{~kg} \mathrm{ha}^{-1}$

†Contaminated with varying levels of TCDD.

$\ddagger$ Acid equivalent is the mass of pure acid that results from complete de-esterification or deamination of salts and esters. Total ester masses are approximately $20 \%$ greater.

§80-20\% mixture when mixed with Agent Green. Agent Green was never sprayed alone but was immediately mixed with Agent Pink for spraying.

IIProprietary product of Dow Chemical Company (Tordon 101).

I Ansul Chemical Co. product Phytar 560 was the only arsenical in use before July 1969. 
After Agent Orange spraying ended in May 1970, the USAF was required to dispose of very large stockpiles of surplus herbicide that were ultimately incinerated aboard the M/T Vulcanus in 1977. (The US government had also assumed liability for large unblended inventories of 2,4,5-T and 2,4-D from contracted suppliers, either paying for storage or stockpiling the chemicals at Kelly Air Force Base, Texas, in December 1970 (ref. 25). We do not know the fate of the stockpiles.)

TCDD concentrations varied widely in the mixtures. The USAF was required to provide the US Environmental Protection Agency with an Environmental Impact Statement (EIS) prior to incineration $^{26}$. The EIS sheds light on TCDD levels in the over three million litres of herbicide stockpiled at the Naval Construction Battalion Center (NCBC), Gulfport, Mississippi, and the approximately 26,000 208-litre barrels in the Johnston Island stockpile.

TCDD concentrations ranged from 6.2 to 14.3 p.p.m., and averaged 13.25 p.p.m. in samples drawn for incineration-effluent modelling studies from 28 different NCBC barrels chosen by the USAF as representative of the seven manufacturers of the NCBC stockpile $^{26}$. However, in other samples drawn from the NCBC stockpile, the TCDD range was about 0.05 to 13.3 p.p.m. (weighted average 1.77 p.p.m.). (NAS-1974, however, calculated a range of $<0.05$ to 17.0 p.p.m., and an arithmetic mean of 2.99 p.p.m. from the same analytical data ${ }^{2}$.) The large discrepancies between the effluent modelling study and the other samples analysed by the
USAF and NAS-1974 can be explained by information in the background analytical documentation in which runs analysed by NAS-1974 are consistent with the 'low dioxin' analytical series ${ }^{27,28}$. The documentation also reports dioxin levels to be heterogeneous, even within production runs. USAF chemists had concluded that generalization from tested barrels to untested ones in the same production batch was not reliable. NAS-1974 appears not to have been provided information either on the heterogeneity of production runs or that they were generalizing from data consistent with a 'low dioxin' analytical series.

Two hundred random samples from the Johnston Island stockpile were also analysed for TCDD content. The Johnston Island stockpile is likely to have been primarily contracted for in 1967 or later and to consist almost exclusively of Agent Orange, because Agents Purple, Pink and Green were not manufactured after the use of Agent Orange began ${ }^{29}$ and in mid-1966 Ranch Hand missions were curtailed because of a severe herbicide shortage ${ }^{17}$. NAS-1974 calculated a mean TCDD level of 1.91 p.p.m. $\pm 20 \%$ for the stockpile $^{2}$. USAF documentation that is widely viewed as authoritative ${ }^{18}$, however, disputes this mean and contends that the four highest values (17, 22, 33 and 47 p.p.m.) must have been Agent Purple, and not Agent Orange, because these values exceeded the mean reported for the NCBC inventory, citing a personal communication from a military officer who recalled that as many as 20 drums of Agent Purple may have been present in the stockpile and redrummed into


Figure 1 Herbicide projects, targets and spraying ${ }^{19}$. a, Spraying operations were directed at specific targets, 487 of which are shown. Labels in a refer to areas blown up in the corresponding parts of Figs 1 and 2. b. Some areas were targeted in multiple projects at different times: black box, 1964; red boxes, 1965; green boxes, 1966. c, We identified targets active before 1965; at least 4.7 million litres of herbicides were used to destroy 33,339 ha of crops and defoliate 101,300 ha of land. Dioxin contamination may be particularly relevant for this time period. $\mathbf{d}$. Correspondence between HERBS file Agents Orange and White mission paths (orange and white lines) and target boxes, three of which enclose a railroad right-of-way. In Figs 1 and 2, waterways such as canals and rivers are shown in blue.
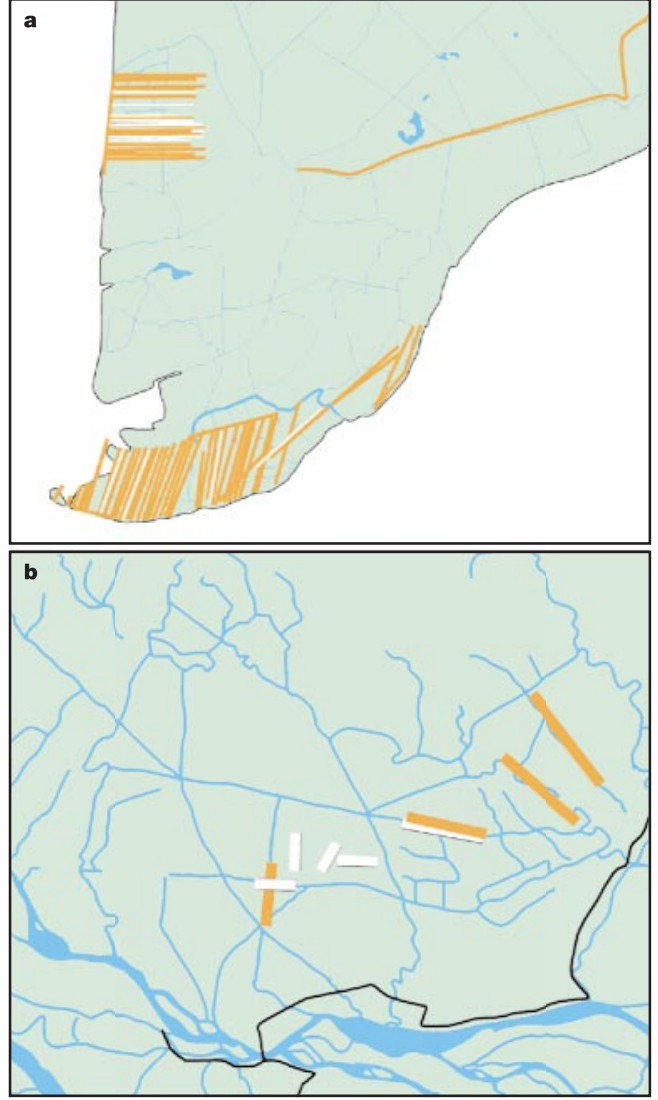

Figure 2 We could not locate target documentation for half the Ranch Hand missions on the HERBS file. a, Missions clearly directed at specific targets. Our current work is to identify probable targets through such mapping. Colours represent the flight paths of spray missions delivering Agents Orange and White $\mathbf{b}$, HERBS file problem. Some purposes defined in the HERBS file documentation ${ }^{3}$, such as waterways and communication lines, are often labelled defoliation in the spray tapes, as shown. NAS-1974 and others have analysed spraying by HERBS file purpose but this is inaccurate. 

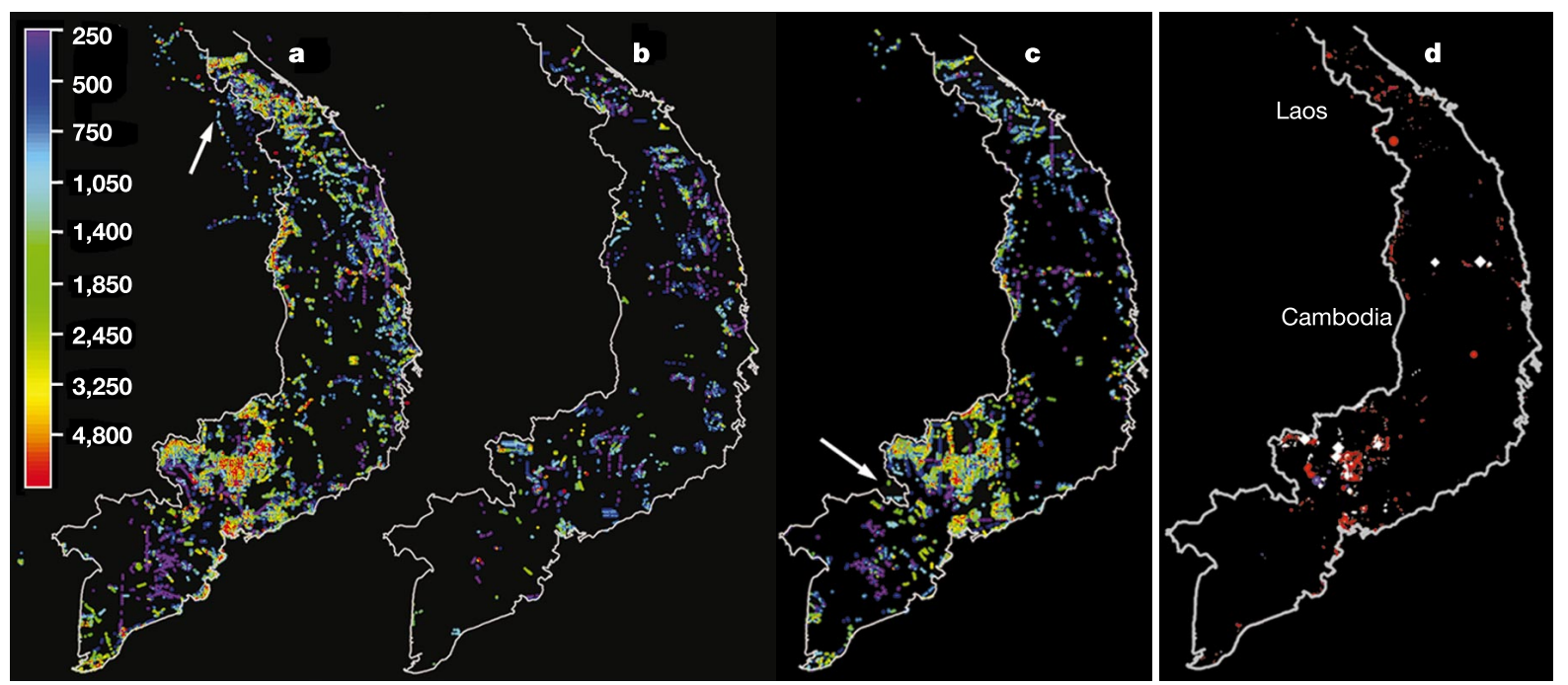

Figure $\mathbf{3}$ Volumes of herbicide sprayed. $\mathbf{a}, \mathbf{b}$ and $\mathbf{c}$ represent known volumes of Agents Orange, White and Blue, respectively, sprayed by US military forces in RVN, 1961-1971. Volumes are calculated for individual grids spaced at 0.01 degrees $\left(\sim 1.2 \mathrm{~km}^{2}\right)$, that divide up Vietnam in a geographic information system developed by $\mathrm{us}^{45}$. Colours in $\mathbf{a}, \mathbf{b}$ and $\mathbf{c}$ correspond to volumes as shown in key. Arrows in a and $\mathbf{c}$ point to missions in Laos and in the Parrot's Beak region of Cambodia, respectively. $\mathbf{d}$, Grids sprayed with volumes greater than 4,800 I (about 10\% of total), with marker size increasing in proportion to volume and colours corresponding to herbicide codenames. All herbicides containing 2,4,5-T are represented by orange markers.
Agent Orange containers. (The hypergeometric probability of selecting four of the 20 Agent Purple drums from the stockpile is $1.32 \times 10^{-5}$.) In fact, the range observed is completely consistent with the USAF's own analysis of the range and heterogeneity of TCDD levels ${ }^{27,28}$. By 1988, Young, the senior author of the USAF documentation, dropped the word "may" and simply reported the four high values to have been Agent Purple ${ }^{30}$. This latter reference has been relied upon as authoritative by the $\mathrm{IOM}^{8}$, and many others.

A 1971 NAS-1974 analysis of six core soil samples collected from the central calibration grid at Pran Buri, Thailand, over which all ARPA test flights had flown, found TCDD levels ranging from nondetectable $(<0.0012$ p.p.m.) to 0.0233 p.p.m. and 2,4,5-T residue from non-detectable ( $<0.02$ p.p.m.) to 0.61 p.p.m.. NAS-1974 estimated the original herbicide to have contained $<3$ to 50 p.p.m. TCDD, consistent with the range observed in the Johnston Island stockpile $^{2}$. (The USAF documentation ${ }^{18}$ incorrectly asserts that NAS-1974 had erred in attributing the TCDD to Agent Orange rather than to Agents Purple and Pink. These misstated findings are used as further rationale for assuming the four high TCDD values to have been Agent Purple.)

Although Agent Purple is, indeed, likely to have been more highly contaminated with TCDD (an archived sample of Agent Purple at Eglin Air Force Base contained 45 p.p.m. TCDD ${ }^{18}$ and historical TCDD contamination data show early 1960s contamination levels to have been much higher $)^{20}$, it is also likely that mean TCDD levels in Agent Orange were far higher than 3 p.p.m. for much of the herbicide used. An average value closer to 13 p.p.m. may be more realistic.

If 3 p.p.m., the mean associated with the 'low dioxin' series is conservatively applied to the new inventory we have presented here, the estimate for TCDD present in the spray grows to $221 \mathrm{~kg}$ from NAS-1974 estimates of 106-163 kg. Applying 32.8 p.p.m. and 65.5 p.p.m. as the average TCDD in Agents Purple and Pink, we obtain an additional $165 \mathrm{~kg}$, or $366 \mathrm{~kg}$ in total (which still does not take into account the herbicides sprayed by RVN forces, and possibly by US Army and Navy forces by trucks, boats, hand sprayers and helicopters, nor the more than 400,000 l of Agent Pink shown in procurement records but not found in any recorded missions). If, indeed, dioxin contamination of Agent Orange could be fourfold or more higher, then this increased dioxin load grows proportionally. It is also possible that some missions recorded as having dispersed Agent Orange did, in fact, spray the much more highly contaminated but unaccounted-for Agent Pink, but we know of no way to determine this. It is more likely that the unaccountedfor herbicides were used by Vietnamese troops, although about 50,000 l of Agent Pink do appear on the 1965 inventory.

\section{Estimates of population exposure to herbicides}

A Hamlet Evaluation System (HES) in which US district advisors and Vietnamese district chiefs filled out monthly political survey and census forms was established in June 1967 and a gazetteer of place names and precise geographical locations was also created. The HES data provide a comprehensive rural census that permits us to estimate the numbers of hamlets and size of the population directly sprayed upon ${ }^{31}$. HES files were not made available to NAS1974 early enough to permit analyses ${ }^{2}$.

More than 20,585 unique hamlets are represented in the corrected version of the database used here. Population data are not

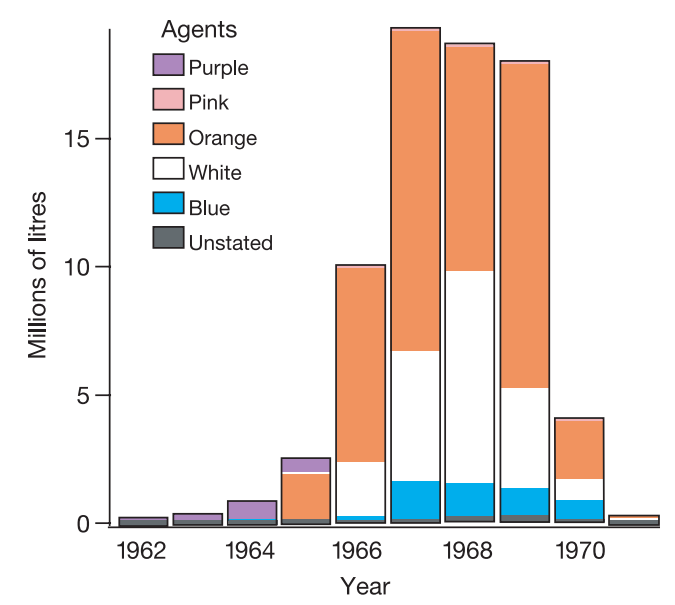

Figure 4 Litres of herbicides sprayed over 1962-1971. The data are taken from the corrected HERBS file and do not include Dinoxol and Trinoxol used in 1961. 


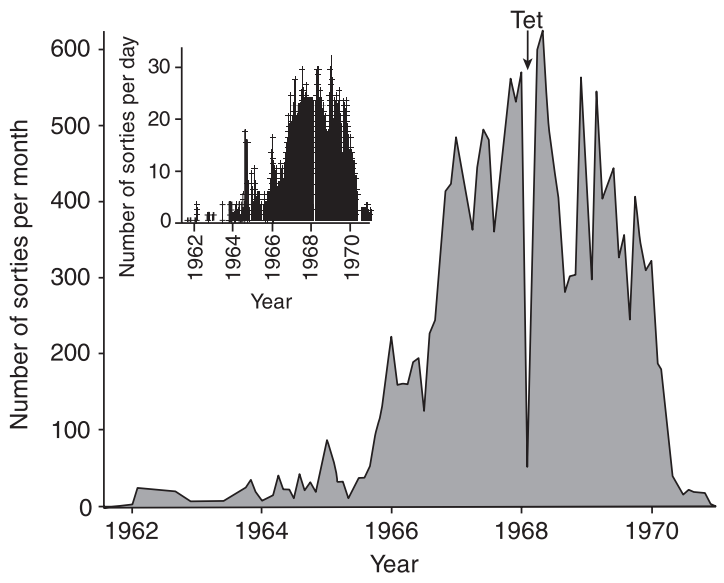

Figure 5 Time course of herbicide sorties. At least 19,905 sorties were run between 1961-1971 (1-34 daily, with a daily average of 10.7 sorties). These data disagree with USAF estimates ${ }^{18}$. The number of daily sorties mirrors the course of the Vietnam War itself: a slow build-up, maximum activity 1968-1969, then a slow but steady decline. The abrupt spraying drop-off at the end of January 1968 corresponds to the Tet Offensive wherein North Vietnamese forces carried out massive, coordinated attacks throughout RVN for nearly 2.5 months. Spray equipment was removed from Ranch Hand aircraft and crew and aircraft participated in airlift operations.

available for $18 \%$ of these hamlets and population data are not systematically reported each month for all years. Among the hamlets with some population data, 3,181 were sprayed directly and at least 2.1 million but perhaps as many as 4.8 million people would have been present during the spraying. Another 1,430 hamlets were also sprayed, but we cannot estimate the population involved. In all, at least 3,851 out of 5,958 known fixed-wing missions had flight paths directly over the hamlet coordinates given in the HES and gazetteer data and about 35\% of the total herbicide sprayed was flown by these missions, although, in general, flight paths extended beyond hamlet borders.

\section{Aborted missions and emergency dumps}

Forty-two missions originally intended to spray 120,0001 of herbicide are known to have ended with emergency herbicide dumps where the chemical was jettisoned in about $30 \mathrm{~s}$, compared to the usual 4 to $5 \mathrm{~min}$. At least five herbicide-loaded aircraft crashed. Hundreds of other missions were aborted after take-off because of poor weather at the target site, heavy anti-aircraft fire, or mechanical problems. Such aircraft returned to base with herbicide load intact. It has been erroneously reported that aborted missions automatically dumped herbicide before landing ${ }^{32}$. Many flights were 'aborted' before take-off because of mechanical problems. One extensive but incomplete list of aborted missions is contained in a large-format uncorrected version of the HERBS file, known as the Map Book, which has served as the basis for much analysis of potential exposure, particularly by Vietnamese scientists ${ }^{33}$. When the Map Book list is checked against the USAF Daily Air Activities Reports (DAARS), it is found to consist primarily of mechanical aborts, not herbicide dumps. Conversely, the list does not contain many actual dumps identified by CRUR and has other inaccuracies which have been corrected over the years by the DoD and now by us.

In 1971, NAS-1974 analysed five soil samples from an area in which about 37001 of Agent Orange had been dumped in December 1968. No 2,4,5-T could be detected. TCDD was not analysed ${ }^{34}$. Aborted missions may not represent the significant source of exposure that it has been represented to be by others, and studies which have relied on the uncorrected data in the Map Book will, of necessity, be inaccurate.
Table 2 Estimated area and frequency of spraying

\begin{tabular}{|c|c|c|}
\hline \multirow{2}{*}{ Times sprayed } & \multicolumn{2}{|c|}{ Hectares } \\
\hline & All herbicides & 2,4,5-T herbicides \\
\hline 1 & 368,556 & 343,426 \\
\hline 2 & 369,844 & 332,249 \\
\hline 3 & 361,862 & 275,770 \\
\hline 4 & 341,037 & 236,232 \\
\hline 5 & 272,709 & 153,192 \\
\hline 6 & 216,724 & 119,127 \\
\hline 7 & 153,391 & 75,062 \\
\hline 8 & 138,610 & 51,371 \\
\hline 9 & 115,103 & 32,988 \\
\hline $10+$ & 293,461 & 60,316 \\
\hline Total ha & $2,631,297$ & $1,679,734$ \\
\hline
\end{tabular}

Frequency of spraying is the number of times spray mission flight paths overflew grids in Vietnam GIS developed for herbicide exposure assessment ${ }^{45}$.

\section{Discarded drums}

Approximately two litres of herbicide residue remains in the 208litre barrel after it has been 'emptied'. Typically about $20 \%$ of the residue remains after three rinses. Residue, on average, contained $5.96 \mathrm{mg}$ of TCDD, arising from heavily contaminated herbicides and about $1.25 \mathrm{mg}$ per drum from 'low dioxin' herbicides ${ }^{26}$. Barrel residues had led to inadvertent defoliation of trees and gardens in Da Nang, Nha Trang, Bien Hoa, Phu Cat and Saigon civilian areas near USAF airbases that handled the herbicides when the empty barrels were transported to local merchants for commercial uses ${ }^{35}$. Improved handling procedures were adopted in 1969 following the Da Nang defoliation incident but the ultimate fate of most of the empty barrels is not known and the extent to which people who used the barrels for other purposes may have been exposed is not known.

\section{Spraying in Laos and Cambodia}

Operation Ranch Hand flew its first missions outside RVN in December 1965 to defoliate the major reinforcement and supply route through Laos known as the 'Ho Chi Minh trail'. Known spraying was above the 17th parallel (the northern border of RVN), along Routes 92, 922, 96 and 965 below Tchpone and the Sihanouk Trail that went from Laos to Cambodia. Missions in both countries below the 17th parallel can clearly be seen in Fig. 3a and c. A small amount of crop destruction using Agent Blue was also documented. Laos was also the site of a brief experiment to determine whether F$4 \mathrm{E}$ Phantom II jet fighters could successfully be used to carry out spray operations and avoid anti-aircraft fire. At least five F-4E missions were flown until a fighter was shot down and the strategy was abandoned. Documentation of spray activities in Laos is incomplete. The Services-HERBS file shows flight paths for 210 missions, which sprayed about 1.8 million litres. NARA-held documentation shows as much as $14 \%$ more herbicides as having been sprayed but no coordinates are given so that these data cannot be included in the revised HERBS file ${ }^{36}$.

Unlike in Laos, it was official US policy to avoid spraying Cambodia either directly or indirectly by spray drift ${ }^{37}$ (cited by $\mathrm{Cecil}^{38}$ ). Records show several heavily sprayed regions of RVN, near Cambodia. The HERBS file shows one five-aircraft Ranch Hand mission dispersing approximately 19,000 l of Agent Orange on 5 April 1969 inside Cambodia. Another nine missions dispersed about 136,0001 of Agent Orange while partly over Cambodian territory (Fig. 3c). At the typical rate of $281 \mathrm{ha}^{-1}$ this would cover about 5,500 ha. Undocumented spray drift may have also occurred. In May 1969 a diplomatic crisis arose when Cambodia charged the US with repeatedly spraying it and defoliating 70,930 ha; evidence of defoliation was confirmed by visiting foreign scientists ${ }^{39}$. Cambodian claims seem to be exaggerated in that to achieve the extent of alleged defoliation nearly half of the Ranch Hand flights for AprilMay 1969 would have to have been directed towards Cambodia. 
Records are not available to resolve the controversy, particularly since the area was devastated by US B-52 bombing raids in 1970 .

\section{Discussion}

The Vietnam War ended in 1975, yet no large-scale epidemiological study of herbicides and the health of either the Vietnamese population or war veterans has been carried out. Discussions of health and ecology studies in Vietnam have recently taken place ${ }^{40}$. During the course of developing an exposure methodology, we have unexpectedly come upon primary data which expanded existing herbicide spraying databases and could help guide the design of human health and of environmental studies.

NAS-1974 found the HERBS file to be a powerful tool for studying exposure to herbicides. The concordance between HERBS file mission coordinates, operational folders, and the precise locations of roadways, rail lines, power lines, canals and so on given in modern mapping software increases our confidence in the HERBS file. Viewing the HERBS file as a carefully planned targetbased military exercise, rather than chronological unrelated missions criss-crossing RVN in straight-line paths affords a coherent analytical approach.

Our analyses using original operational records raise questions about the spraying data and dioxin contamination relied upon by researchers and policymakers. For example, we find that the '202 Tasks Realized' document used by NAS-1974 assumed missions that are missing from the HERBS file ${ }^{41}$ to represent targeted areas and anticipated spraying rather than operations completed. (Further, the '202 Tasks Realized' document contains many errors, such as misplaced decimal points for subtotals of volume sprayed, which cumulate and greatly exaggerate the total volume $)^{42}$. Therefore, some NAS-1974 estimates of 'missing' spray must be revised downward. On the other hand, dioxin contamination estimates should be revised upward. Comparatively small amounts of Agent Purple and Pink sprayed in Vietnam between 1961-1965 may have deposited a large percentage of the total dioxin.

Large numbers of Vietnamese civilians appear to have been directly exposed to herbicidal agents, some of which were sprayed at levels at least an order of magnitude greater than for similar US domestic purposes ${ }^{20}$. Other analyses being carried out by us show large numbers of American troops also to have been directly exposed or to have served in recently sprayed areas. Areas sprayed during the early years and in the various test sites around the world ${ }^{15}$ may be of particular interest for follow-up ecological and epidemiological studies.

\section{Methods}

We constructed a new version of the HERBS file using operational records for the USAF 12th Air Commando Squadron (ACS), which carried out the Ranch Hand missions and by systematic comparisons of four different versions of the herbicides files found at the US National Archives ${ }^{43}$ and the active file at CRUR. Of 18,087 mission records there were 1,264 non-matches between HERB2REV and the current CRUR file (that is, 2.5 million litres out of more than 66.6 million litres). About $3.4 \%$ of the total volume is represented at CRUR but not the other files. We also identified errors by mapping flight paths and by consistency checking (for example, legs that were very short or very long, over water, and so on). Discrepancies which we could not thus resolve were reviewed by a smal panel of experts. The same panel reviewed each proposed amendment to the HERBS file. A small number of missions which remained ambiguous were discarded. All discarded missions were from the Services-HERBS.

Flight paths for 65 missions of fixed-wing aircraft missions that had been represented in the original HERBS file only by a single point (usually the calculated centre-of-mass) were readily deduced by comparison with similar missions or known targets. (Some missions are correctly represented as single points because they document perimeter spraying carried out by spraying specific discrete points, such as outside base camps near guard posts.) The revised file contains 9,141 missions, primarily by air, but also using other means of delivery.

We used digitizing software ${ }^{44}$ to derive the longitudes and latitudes defining the target perimeters from hand-drawn maps in the USAF Project Folders ${ }^{19}$. For folders with no map we extracted the Universal Transverse Mercator (UTM) coordinates from written descriptions of the targets and entered them into a Geographic Information System (GIS) which we created ${ }^{45}$, similar to a databank model created by NAS-1974 (we are willing to assist researchers in using our GIS software for estimating exposure using these data).

Population and hamlet exposure estimates used data contained in the HES and Vietnam gazetteer data files ${ }^{31}$. Each hamlet location was assigned a grid identifier and proximity to spray was calculated using our GIS system software.

Received 6 December 2002; accepted 4 March 2003; doi:10.1038/nature01537.

1. Buckingham, W. A. Jr Operation Ranch Hand: The Air Force and Herbicides in Southeast Asia 19611971 (Office of United States Air Force History, Washington DC, 1982).

2. National Research Council Committee on the Effects of Herbicides in Vietnam. The Effects of Herbicides in South Vietnam. Part A. Summary and Conclusions (National Academy of Sciences Press, Washington DC, 1974).

3. Data Management Agency, US MACV. Herbicide Report System (HERBS). Document No. DARU07 (US Military Assistance Command Vietnam, San Francisco, 1970).

4. Heizer, J. R. Data Quality Analysis of the HERB 01 Data File. No. MTR-5105 (The Mitre Corporation, Washington DC, 21 April 1971).

5. Wiersma, G. B. Ecological Impact of Antiplant Agents and Implications for Future Use. Report No. ACN 16223 (US Army Combat Developments Command, Institute of Land Combat, Fort Belvoir, VA, July 1970).

6. Huddle, F. P. A Technology Assessment of the Vietnam Defoliant Matter. Report to the Subcommittee on Science, Research and Development, Committee on Science and Astronautics. (Science Policy Research Division, Legislative Reference Service, Library of Congress Serial F, Washington DC, 8 August 1969).

7. Courtney, K. D. et al. Teratogenic evaluation of 2,4,5-T. Science 168, 864-866 (1970).

8. Institute of Medicine Committee to Review the Health Effects in Vietnam Veterans of Exposure to Herbicides. Veterans and Agent Orange: Health Effects of Herbicides Used in Vietnam (National Academy of Sciences Press, Washington DC, 1994).

9. Committee on the Assessment of Wartime Exposure to Herbicides in Vietnam, Institute of Medicine. Characterizing Exposure of Veterans to Agent Orange and Other Herbicides Used in Vietnam: Scientific Considerations Regarding a Request for Proposals for Research (National Academy of Sciences Press, Washington DC, 1997).

10. Harrigan, E. T. Calibration Test of the UC-123K/A/A45Y-1 Spray System. Technical Report No. ADTC-TR-70-36 (Armament and Development Test Center, Eglin AFB Florida, February 1970).

11. Thayer, T. C. War without Fronts: The American Experience in Vietnam. Westview Special Studies in Military Affairs (Westview Press, Boulder, CO, 1985).

12. Brown, J. W. Vegetational Spray Tests in South Vietnam (US Army Chemical Corps Biological Laboratories, Fort Detrick, MD, 1962).

13. Brown, J. W. Vegetational Spray Tests in South Vietnam (Supplement U) (US Army Chemical Corps Biological Laboratories, Fort Detrick, MD, 1962).

14. Olenchuk, P. G., Burke, R. T., Henderson, O. K. \& Davis, W. E. Evaluation of Herbicide Operations in the Republic of Vietnam (September 1962-September 1963) (US Military Assistance Command, Vietnam, APO San Francisco, 10 October 1963).

15. Darrow, R. A., Truchelat, G. B. \& Bartlett, C. M. OCONUS Defoliation Test Program (US Army Biological Center, Fort Detrick, MD, July 1966).

16. Cecil, P. F. Herbicidal Warfare. The Ranch Hand Project in Vietnam (Praeger Scientific, New York, 1986).

17. Collins, C. V. Herbicide Operations in Southeast Asia July 1961-June 1967. Report No. DTEC 67-0020 (HQ PACAF, Directorate, Tactical Evaluation, CHECO Division, APO San Francisco, 11 October 1967).

18. Young, A. L., Calcagni, J. A., Thalken, C. E. \& Tremblay, J. W. The Toxicology, Environmental Fate and Human Risk of Herbicide Orange and Its Associated Dioxin. US AF Technical Report OEHL-TR-78-92 (Brooks AFB, TX, 1978).

19. US Department of Defense. Records of the US Forces in Southeast Asia, Headquarters, Military Assistance Command Vietnam (MACV), Assistant Chief of Staff for Operations (J3), Chemical Operations Division (MACJ-3-09). Herbicide Operations Plans (1966-1967) series, Record Group 472 (National Archives and Records Administration, College Park, MD; 1950-75).

20. Panel on Herbicides of the President's Science Advisory Committee. Report on 2,4,5-T (Executive Office of the President, Office of Science and Technology, Washington DC, March 1971).

21. Dwernychuk, L. W. et al. Dioxin reservoirs in southern Viet Nam-a legacy of Agent Orange. Chemosphere 47, 117-137 (2002).

22. Young, A. L. Ecological Studies on a Herbicide-equipment Test Area (TA C-52A). (Air Force Armament Laboratory, Eglin AFB, 1974).

23. Letter from Colonel W. T. Moseley to Dr C. E. Minarik. No. MACC007 (US Military Assistance Vietnam, APO San Francisco, 10 May 1967).

24. Craig, D. A. Use of Herbicides in Southeast Asia. Historical Report. (San Antonio Logistics Center, Directorate of Energy Management, San Antonio AFB, TX, 1975).

25. Darrow, R. A. Historical, Logistical, Political and Technical Aspects of the Herbicide/Defoliant Program, 1967-1971: A Resume of the Activities of the Subcommittee on Defoliation/Anticrop Systems for JTCG/CB. (Vegetation Control Committee, Fort Detrick, MD, September 1971).

26. Revised Draft Environmental Impact Statement. Disposition of Orange Herbicide by Incineration. Report No. AF-ES-72-2D. (Department of the Air Force, Washington, DC, April 1974).

27. Hughes, B. M. et al. Analytical Methodology for Herbicide Orange. Vol 1: Determination of Chemical Composition. No. ARL 75-0110 (Wright-Patterson AFB, Aerospace Research Laboratories, OH, May 1975).

28. Fee, D. C., Hughes, B. M., Tiernan, T. O., Hill, C. E. \& Taylor, M. L. Analytical Methodology for Herbicide Orange. Vol II: Determination of Origin of USAF Stocks. No. ARL 75-0110 (Wright-Patterson AFB, Aerospace Research Laboratories, OH, May 1975).

29. Darrow, R. A., Irish, K. R. \& Minarik, C. E. Herbicides Used in Southeast Asia. (United States Army Plant Sciences Laboratories, Fort Detrick, Maryland, 1969).

30. Young, A. L. \& Reggiani, G. M. Agent Orange and Its Associated Dioxin: Assessment of a Controversy (Elsevier, Amsterdam, 1988).

31. US Department of Defense. Hamlet Evaluation System (HES). [Electronic Records]. Record Group 330 (National Archives and Records Administration Center for Electronic Records, College Park, MD, 1967-74).

32. Orians, G. H. \& Pfeiffer, E. W. United States goals in Vietnam. Science 169, 1030 (1970).

33. Smith, C. \& Watkins, D. The Vietnam Map Book. Self-help Guide to Herbicides Exposure. (Winter Soldier Archive, Berkeley, CA, November 1981).

34. Blackman, G. E., Fryer, J. D., Lang, A. \& Newton, M. The Effects of Herbicides in South Vietnam. Part B: 
Working Papers. Persistence and Disappearance of Herbicides in Tropical Soils (National Academy of Sciences-National Research Council, Washington DC, 1974).

35. US Military Assistance Command, Vietnam. Vietnam Lessons Learned No. 74: Accidental Herbicide Damage (MACV, APO San Francisco, 15 September 1969).

36. US Department of Defense Records of the US Forces in Southeast Asia, 1950-1975, Headquarters, Military Assistance Command Vietnam (MACV), Assistant Chief of Staff for Operations (J3) Record Group 472 (National Archives and Records Administration, Modern Military Records LICON, Textual Archives Services Division, College Park, MD, 1950-75).

37. American Embassy, Phnom Penh. Telegram No. 875, NSF-VN Vol. X, Box 196-98 (John F. Kennedy Presidential Library, Boston, MA, 18 May 1963).

38. Cecil, P. F. The Air Force Ranch Hand Project in Southeast Asia: Operations and Consequences PhD dissertation, Texas A\&M Univ. (1984).

39. Hay, A. The Chemical Scythe: Lessons of 2,4,5-T and Dioxin 187-195 (Plenum, New York, 1982).

40. Cyranoski, D. US and Vietnam join forces to count cost of Agent Orange. Nature 416, 262 (2002).

41. '202 Committee' List of 202 Task (sic) Realized From January 1962 to September 1965. (Military Assistance Command, Vietnam, Saigon, undated).

42. Dashiell, T. R. (Office of the Director of Defense Research and Engineering) Comments to Dr. P. Kunstadter's Comparison of HERBS and 202 Records (Memorandum to P. Ross, National Academy of Sciences, 11 July 1973).
43. US Department of Defense Herbicide Files, 1965-1970. Record Group 30 (National Archives and Records Administration Center for Electronic Records, College Park, MD, 1965-70)

44. R2V Software Able Software Corp, 2000; www.ablesw.com.

45. Stellman, J. M. et al. A Geographic Information System for characterizing exposure to Agent Orange and other herbicides in Vietnam. Environ. Health Perspect 111, 321-323 (2003).

Acknowledgements This research was supported by the National Academy of Sciences, the Department of Veterans Affairs and USPHS at the National Cancer Institute. We thank

D. Hakenson and his staff at the US Armed Services Center for Research of Unit Records for technical support and access to military records; the staff of the National Archives and Records Administration, particularly R. Boylan and M. O. Adams; N. Heim for assistance with

illustrations and F. Benjamin for assistance with military records. R.C. is a retired member of the US Army

Competing interests statement The authors declare that they have no competing financial interests.

Correspondence and requests for materials should be addressed to J.M.S.

(e-mail: jms13@columbia.edu). 